produce very good growth. Mixtures of nineteen and seventeen amino-acids were almost as effective as casein. The omission of dispensable amino-acids led to mixtures of from fourteen to eleven amino-acids, resulting in poor growth. Only a slight improvement could be brought about by varying the relative proportions of amino-acids present.

By omitting the amino-acids one at a time from the mixture of seventeen previously employed, the following were found to be indispensable for the growth of the larva: glycine, $l$-leucine, $d l$-isoleucine, $l$-histidine, $l$-arginine, $l$-lysine, $l$-tryptophane, $d l$ threonine, $d l$-phenylalanine, and $d l$-methionine. The status of $d l$-valine could not be determined while using yeast autolysate in the medium, since the autolysate was found to contain appreciable amounts of valine. 'Folic acid' could not be substituted for autolysate in amino-acid studies because no growth resulted, even when all other known growth requirements were satisfied.

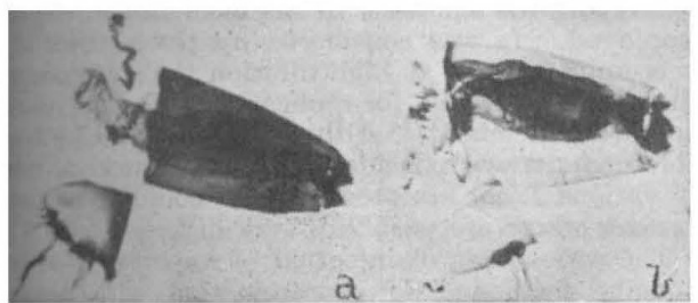

SIPHON AND SADDLE OF (a) NORMALLY PIGMENTED FOURTH-STAGE IARVA; AND (b) UNPIGMENTED FOURTH-STAGE LARVA

The severity of the effect of deficiency of an essential amino-acid varied, but in the absence of each of several amino-acids no growth whatever could be observed. Perhaps the most interesting observation made in these studies was the effect of a medium deficient in phenylalanine or tyrosine. In the absence of added phenylalanine or tyrosine no growth takes place. With suboptimal amounts, the larvæ seem normal in every respect except that they appear to be wholly unpigmented. The accompanying photographs of the siphon and saddle of a normally pig. mented fourth-stage larva and of the same area in an unpigmented larva serve to illustrate the ghost-like appearance of the latter. The pupæ, too, are lacking in pigment, but the adults which emerge are fully and characteristically pigmented. Two types of intermediate pigmentation were observed: in the first, black pigment begins to appear only in the fourth-instar larva; in the second, the use of substances analogous to tyrosine produced intermediate shades of pigmentation (Table 2). Both effects may

Table 2. Pigmentation of Mosquito lakV a in a medidM Composed OF 0.5 PER CENT GELATINE, SUPPLEMENTARY AMINO-ACIDS (NO PHENYLALANINE OR TYROSINE) AND YEAST AUTOLYSATE

$$
\text { Compound tested }
$$

busal medium only

$d l$-phenylalanine

$d l$-phenylalanine

l-tyrosine

l-3-aminotyrosine

l-3,4-dihydroxyphenylalanine $†$

tyramine hydrochloride

$d l-\alpha$-aminophenylacetic acid

$p$-aminophenylacetic acid

* The significance of the symbols used is as follows

- , white ; no yellow pigment visible.

0 , siphon and saddle clear yellow; no darkening.

00 , siphon and saddle bright yellow ; no darkening.

+ , slight darkening of siphon and saddle.

++ , siphon definitely darkened; saddle with a large clearly marked dark area dorsally.

† In this instance third-stage larvæ were examined. In all other cases fourth-stage pelts were used to assess the degree of pigmentation. be interpreted on the basis of the observation of Serra ${ }^{2}$ that the diversity of colours of the melanins extracted from hairs of different hues results from the combination of varying proportions of melanoid pigment and protein. Lack of pigmentation does not appear to affect the rate of growth or survival.

Despite the presence of large amounts of $d l$ methionine in the medium (up to $1.0 \mathrm{gm}$. per 1.), the omission of the relatively small quantity of $l$-cystine customarily used (20 mgm. per I.) has an effect on the emergence of adult mosquitoes. The majority of the adults formed from the pupæ are found dead in the medium with only the upper half of the body projecting from the pupal case. Examination of the adults failed to reveal any obvious malformations. The same effect was occasionally observed in other amino-acid media, but was particularly prominent in the absence of added cystine. Cystine could be replaced by glutathione, but not by $d l$ homocystine.

The detailed findings, of which only the more alient features have been summarized above, will be sublished later, and full acknowledgment made to hose who so kindly provided a number of the naterials used in this work. Here we should like o thank Miss M. Currie and Mr. J. M. Thorp for echnical assistance, and Mr. F. A. Brandt for the shotographs.

Golberg, L., De Meillon, B., and Lavoipierre, M., Nature, 154, 608 (1944).

Angier, R. B., Boothe, J. H., Hutchings, B. L., Mowat, J. H., Semb, J., Stokstad, E. L. R., SubbaRow, Y., Waller, C. W., Cosulich, D. B., Fahrenbach, M.' J., Hultquist, M. E., Kuh, E., Northey, E. H., Seeger, D. R., Sickels, J. P., and Smith, J. M., jun., Science,
103, 667 (1946).

${ }^{3}$ Hutchings, B. L., Stokstad, E. L. R., Bohonos, N., and Slobodkin, N. H., Science, 99, $371(1944)$.

"Scott, M. L., Norris, L. C., and Heuser, G. F., Science, 103, 303 (1946). "Wigglesworth, V. B., "Principles of Insect Physiology" (London:
Methuen, 1939).

' Fraenkel, G., and Blewett, M., Biochem. J., 37, 692 (1943)

' Cailleau, R., Ann. Inst. Pasteur, 59, 293 (1937).

${ }^{8}$ Haslewood, G. A. D., Nature, 154, 29 (1944).

'Serra, J. A., Nature, 157, 771 (1946).

\section{BACTERIOLOGY OF WATER}

$\mathrm{D}$ IFFERENT problems involving micro-organisms in fresh water and the importance of fundamental and co-operative research in this field were considered at a symposium on water bacteriology which was held at the University of Reading on July 10 , as part of the programme of the annual general meeting of the Society for Applied Bacteriology.

Dr. F. Greenshields (Metropolitan Water Board) presented a paper concerned with water-supply biology, in which he pointed out that pollution of lowland rivers in Britain in recent decades with drainage from arable land, and with sewage and trade-waste effluents, is accelerating the biological maturation of downstream reservoirs. The production of dense crops of phytoplankton, leading to excessive clogging of the filters or to the production of objectionable tastes and odours, makes it increasingly difficult to make stored water available to the consumer at certain seasons. The application of algicides to established growths is of palliative value only, and utilization of other methods of scientific control is hampered by ignorance of fundamental knowledge of growth requirements of different organisms. The increasing spread of limnological knowledge through 
the medium of the Freshwater Biological Association, and the contributions of the Water Pollution Research Laboratory of the Department of Scientific and Industrial Research to the improvement in purification of sewage and trade wastes, should go far to achieve ultimate success in the effective control of algal growths.

Discussion of the paper was directed to the generally unsatisfactory procedure of chlorinating sewage effluents, which is not a feature in Great Britain, rather than endeavouring to obtain a more highly purified effluent ; chlorination leaves the biochemical demand unsatisfied, and in the presence of gas works liquors may lead to production of cyanogen chloride -a substance of considerable toxicity to fish. It was considered that the construction of small-scale experimental reservoirs to follow up laboratory experiments is not so desirable as the use of reservoirs already established.

Difficulties which arise in assessing water quality from laboratory tests when coliform and pathogenic intestinal organisms develop outside their normal habitats were considered in a paper by Dr. E. Windle Taylor (Metropolitan Water Board) read by Mr. Burman. In the early days of the Second World War, it was found that officient disinfection of water-mains after repair was sometimes difficult to achieve, and many investigations were undertaken to improve methods of repair and disinfection of mains. It was found that notwithstanding the greatest care that was taken in making a clean and hygienic repair and in the disinfection with chlorine, the raw jute yarn jointing material could itself be a source of subsequent contamination with micro-organisms. All types of coliform organisms, including Bact. coli type $\mathrm{I}$, have been isolated, and it has been shown that some pathogenic intestinal organisms can also thrive on the yarn.

Laboratory experiments have confirmed the experience with samples collected in the distribution system that there are critical temperatures at which these coliform organisms can thrive. At the winter temperature of $4^{\circ} \mathrm{C}$. and thereabouts, yarn is not a factor in the contamination of mains, but above $10^{\circ} \mathrm{C}$. coliform organisms multiply actively in the yarn material. One lactose-fermenting organism having the reactions of Bact. aerogenes, except that it is capable of growing at $44^{\circ} \mathrm{C}$., seems particularly associated with yarn and decaying wood, and on account of its frequent origin it has been christened the 'yarn' organism. Yarn in contact with water will form a breeding ground for pathogenic intestinal bacteria, and the ordinary chloramine residuals remaining in the water would have no disinfectant action. Researches have been undertaken into improving methods of chlorination of mains and into methods of sterilizing and treating joint-packing and also to find substitutes for it.

The paper led to spirited discussion on the specificity of the test involving the ability of Bact. coli type I to ferment lactose in MacConkey broth at $44^{\circ} \mathrm{C}$., and the value of the test in view of the ability of the 'yarn' organism to carry out a similar reaction. It was suggested that if the indole test were used in conjunction with the $44^{\circ} \mathrm{C}$. test it would be possible to distinguish between coli and aerogenes types growing at this temperature. In answer to a question, it was stated that jute was used as a packing material due to its cheapness and availability.

Some of the results obtained during a bacteriological survey of the Warwickshire Avon by the
Water Pollution Research Laboratory in 1945-46 were given by Dr. C. L. Hannay and Irene L. Norton. In view of the fact that the bacterial flora of river water is pre-eminently Gram-negative, it was thought that interesting information might be obtained from counts in the river water of a Grampositive organism the normal habitat of which is fæcal material. Consequently a study was made of fæcal streptococci isolated by means of a buffered glucose broth containing sodium azide. Results of the investigation, which included observations on the effect of sodium azide, showed that the proportion of streptococci isolated from river water which fermented mannitol was very similar to that found elsewhere for streptococci isolated from fæces. No streptococei with characteristics of either Strep. lactis or Strep. bovis were isolated, and it was considered that although the medium appeared to be specific for streptococci of Group $D$, ultimate specificity rests on serological grouping.

The paper evoked considerable discussion chiefly concerning the efficiency of the medium and method employed. It was considered by the authors that it is unlikely that at high dilution the streptococcal chains are disrupted, for replicate counts gave results in good agreement. Although no data had been obtained, it was considered that the survival-rates of various fæcal streptococci and coliform bacteria in river water are probably very different.

The seriousness of infection of imperfectly sealed cans of food due to contamination with cooling water of high bacterial count was discussed by Mr. T. E. Bashford (The Metal Box Co., Ltd.) in a paper entitled "Infected Cooling Water and its Effect on the Spoilage of Canned Foods". Due to methods of manufacture, it is not always possible to have cans with perfect seals, some minute channels being left unsealed. Laboratory experiments showed that the incidence of infection of the cans is greatly affected by the numbers of bacteria in the cooling water. As many canneries are situated in rural districts where the supply of water of low bacterial count is not always available, some method of sterilization should be employed, and tests had shown that chlorination is a suitable method. Dosages of chlorine to the cooling water allowing a chlorine residual of 1-2 p.p.m. and a contact time of $20-30$ min., were found effective in reducing appreciably the numbers of infected cans, but subsequent con. tamination during distribution of faulty cans is always possible. It was suggested during discussion that more effective sealing compounds are required, and that possibly some rubber emulsion containing an antibiotic might be satisfactory in preventing contamination of the can and spoilage of the contents.

Dr. C. B. Taylor, in a paper entitled "Some Aspects of the Bacteriology of Lakes and Streams", pointed out the paradox that water bacteriology of the text. books is largely concerned with studies of organisms which have a normal habitat other than water, and that the Freshwater Biological Association is concerned primarily with fundamental studies of bacteria capable of multiplying in the waters of streams and lakes and in the deposits beneath. Preliminary work already carried out has shown that the distribution of bacteria in lake waters, estimated by plate counts, is largely dependent on water movements, which at times are extremely complex and vary rapidly with changing atmospheric conditions. In order to obtain a properly balanced consideration of "water bacteriology' future work must involve studies of bacteria 
in $(a)$ the water, (b) associated with the plankton, and $(c)$ in the deposits. Work is in progress in connexion with the factors which limit growth of bacteria in lake waters, and it is hoped that the results will serve as an introduction to a more specialized study of the nutrition of water bacteria. As Algæ are the primary producers of organic matter in a large body of water, their association with bacteria in life and during decay is of considerable importance; present work, which has demonstrated that bacteria living on dying cells of the diatom Asterionella are unable to grow on common solid laboratory media, indicates the technical difficulties involved in such studies. Preliminary studies on lake muds has shown that in large bodies of water such autotrophic processes as involve nitrogen and sulphur oxidation are confined largely to the immediate surface layer of the deposits. In the discussion following the paper several speakers emphasized the need for developing work on the bacteriology of water along these lines.

C. B. TAYLOR

\section{PRACTICAL TRAINING OF ELECTRICAL ENGINEERS}

$\mathrm{T}$ HE practical training of the professional electrical engineer is the subject of a report published recently by the Institution of Electrical Engineers*. The report, which is the work of a joint committee comprising representatives of the Institution, the Radio Industry Council and the British Electrical and Allied Manufacturers' Association, makes specific recommendations as to the character and duration of an ordered scheme of practical training, and reviews in some detail various considerations underlying its recommendations.

Where the young engineer has obtained his academic qualification by a full-time university course, the practical training should occupy two years and be termed a 'graduate apprenticeship'. Where, on the other hand, part-time technical education of appropriate standard is being pursued during the industrial apprenticeship, the duration of the practical training should be four years. This is termed a 'student apprenticeship'. Subdivision of the training period is made under three headings : basic mechanical training; basic electrical training; and office training. The first period, occupying roughly half the total time, deals with general manufacturing methods and workshop processes. It is in the second period that attention is directed towards the more specifically electrical aspects of the manufacture of particular types of electrical machinery or apparatus. The title "Office Training" is used to cover the acquisition of experience in the drawing office, planning and progress departments.

During the student apprenticeship it is assumed that the apprentice will be released from work on one day a week to attend a technical college course leading normally to a Higher National Certificate.

Stress is laid upon the value of the personal contacts which the apprentice makes with all classes of industrial personnel during his training period. It is largely through these contacts that he develops his sense of personal responsibility and his appreciation

* The Practical Training of Professional Electrical Engineers. Report of a Committee appointed by the Council of the British Electrical and Allied Manufacturers' Association, the Radio Industry Council, and the Council of the Institution of Electrical Engineers. Pp. 42. (London : Inst. Elect. Eng., 1947.) 18. of the great importance of human relationships in industry. In the same connexion, mention is made of the merits of apprentice associations and similar bodies.

While the general plan developed in this report is based upon conditions obtaining in a relatively large manufacturing organisation, the special considera. tions affecting smaller firms and those specific to the operating side of the industry have also been given detailed attention. It is laid down as axiomatic that practical acquaintance with the basic processes employed in manufacture is needed by every engineer. For organisations such as electricity supply undertakings or telecommunication services, provision is therefore made for a considerable period of 'secondment' of the apprentice to a manufacturing organisation.

Quite apart from its specific recommendations, the report embodies a most careful analysis and appraisal of the duties and functions of the professional engineer and of the purposes towards which the various de. partments of his practical training should be directed. The report does not make specific reference to the important and difficult question of how best to integrate the military service requirement into the training period. It should be mentioned, however, that provision has been made by the Ministry of Labour and National Service for deferment to cover the whole of a five-year period of technical education and practical training. The details of this provision, which are set out in a leaflet, N.L.11, issued by the Ministry, are restated in the June issue of the Journal of the Institution of Electrical Engineers and are the subject of a further comment in the September issue of the Journal.

\section{FORTHCOMING EVENTS}

\section{Monday, October 27}

INSTITUTION of Eleotrioal ENGINEERs (at Savoy Place, Victoria Embankment, London, W.C.2), at 5.30 p.m. -Discussion on "Standardization in the Electrical Industry" (to be opened by the President, Mr. P. Good).

INSTITUTION OF THE RUBBER INDUSTRY, MANCHESTER SECTION (at the Engineers' Club, Albert Square, Manchester), at 6.15 p.m.Mr. B. Gordon Darnton: "Incidentals in Latex Treatment".

\section{Tuesday, October 28}

ROYAL INSTITUTION (at 21 Albemarle Street, Iondon, W.1), at 5.15 p.m. - Sir Edward Salisbury, F.R.S.: "The Vegetation of the and Physical Factors of the Environment".

SHEFTIELD METALLURGICAL ASSOcLation (at 198 West Street, Sheffield), at 7 p.m.-Mr. R. B. Heywood: "Photoelasticity Applied to Design Problems".

SocikTY OF INSTRUMENT TECHNOLOGY (at the Royal Society of Tropical Medicine and Hygiene, Manson House, 26 Portland Place, London, W.1), at 7 p.m. Mr. J. O. V. Vick, Mr. C. Lamond and
Mr. W. Lindsay: "The Organisation of an Instrument Department in an Industrial Works".

\section{Wednesday, October 29}

INSTITUTE OF WELDING (at the Institution of Civil Engineers, Great George Street, London, S.W.1), at 6 p.m.-Mr. J. L. Adam: Presidential Address.

Soctety of Chemical INDUSTRY, Nutrition PaNel of the Food Group (at the Chemical Society, Burlington House, Piccadilly, London, W.1), at 6.30 p.m.-Prof. A. Haddow and Dr. L. A. Elson: "Food and Cancer".

ROYAL INSTITUTE OF CHEMISTRY, LONDON AND SOUTH-EASTERN COUNTrES SEOTION (at Woolwich Polytechnic, Woolwich, London, S.E.18), at 7 p.m.-Mr. J. G. N. Gaskin: "The Examination of Questioned Documents".

\section{Thursday, October 30}

LINNEAN SOcIETY OF LoNDON (at Burlington House, Piccadilly, London, W.1), at 5 p.m.-Rev. Prof. C. E. Raven: "Early Records of British Plants with special reference to Thomas Lawson (1630-91)" ; Dr. W. S. Bristowe: "Notes on the Habits and Prey of Twenty" Species of British Hunting Wasps". 